Received Date : 04-Jun-2016

Revised Date : 09-Nov-2016

Accepted Date : 17-Nov-2016

Article type : Primary Research Articles

\title{
Seasonality constraints to livestock grazing
}

\section{intensity}

\section{Seasonality constraints to grazing intensity}

Tamara Fetzel $^{1^{*}}$, Petr Havlik ${ }^{2}$, Mario Herrero ${ }^{3}$, Karl-Heinz Erb ${ }^{1}$

${ }^{1}$ Institute of Social Ecology Vienna, Alpen-Adria Universitaet Klagenfurt, Wien, Graz, Schottenfeldgasse 29, 1070 Vienna, Austria

${ }^{2}$ Ecosystem Services and Management Program, International Institute for Applied Systems Analysis, Schloßplatz 1, 2361 Laxenburg, Austria.

${ }^{3}$ Commonwealth Scientific and Industrial Research Organisation, 306 Carmody Road, St Lucia, 4067 Qld, Australia

* Corresponding author: Tamara Fetzel (tamara.fetzel@aau.at; tamara@fetzel.eu), T ++43 (0) 1522 4000423

This article has been accepted for publication and undergone full peer review but has not been through the copyediting, typesetting, pagination and proofreading process, which may lead to differences between this version and the Version of Record. Please cite this article as doi: $10.1111 / \mathrm{gcb} .13591$

This article is protected by copyright. All rights reserved. 
Keywords: Grazing intensity, global livestock systems, seasonality, natural grasslands, food security, grassland management

Primary research article

Accepted for publication in Global Change Biology, November 2016

\section{Abstract}

Increasing food production is essential to meet the future food demand of a growing world population. In the light of pressing sustainability challenges like climate change and the importance of the global livestock system for food security as well as GHG emissions, finding ways to increasing food production sustainably and without increasing competition for food crops is essential. Yet, many unknowns relate to livestock grazing, in particular grazing intensity, an essential variable to assess the sustainability of livestock systems. Here we explore ecological limits to grazing intensity (GI; i.e., the fraction of Net Primary Production consumed by grazing animals) by analysing the role of seasonality in natural grasslands. We estimate seasonal limitations to GI by combining monthly Net Primary Production data and a map of global livestock distribution with assumptions on the length of non-favourable periods that can be bridged by livestock (e.g., by browsing dead standing biomass, storage systems or biomass conservation). This allows us to derive a seasonality-limited potential GI, which we compare with the GI prevailing in 2000 . We find that GI in 2000 lies below its potential on $39 \%$ of the total global natural grasslands, which has a potential for increasing biomass extraction of up to $181 \mathrm{MtC} / \mathrm{yr}$. In contrast, on $61 \%$ of the area $\mathrm{Gl}$ exceeds the potential, made possible by management. Mobilizing this potential could increase milk production by $5 \%$, meat production by $4 \%$, or contribute to free up to $2.8 \mathrm{Mio} \mathrm{km}^{2}$ of grassland area at the global scale if the

This article is protected by copyright. All rights reserved. 
numerous socio-ecological constraints can be overcome. We discuss socio-ecological trade-offs, which may reduce the estimated potential considerably and require the estabilishment of sound monitoring systems and an improved understanding of livestock system's role in the Earth system.

\section{Introduction}

Grazing of domesticated livestock is the largest single land use activity (Erb et al. 2007) and provides essential services for humanity: It creates income and nourishment for more than 1.3 billion people (Herrero et al. 2013) and allows for utilization of land that is not suitable for other food production, e.g., crop production (Asner et al. 2004; Thornton 2002). Livestock products are already an essential source of food for many and make up for $17 \%$ of the total global energy intake (Herrero et al. 2009). Livestock systems also play an essential role in global GHG emissions (Godfray et al. 2010; Havlik et al. 2012; Herrero and Thornton 2013). In the light of the projected population and income growth, demand for livestock products is expected to further increase until 2050 (Tilman and Clark 2014). However, increasing food production from grasslands, e.g., by increasing feeding conversion ratios through improved feedstuff or land-use expansion, relates to massive trade-offs, such as carbon and biodiversity losses (Steinfeld and Gerber 2010; Herrero and Thornton 2013, Peters et al. 2013; Petz et al. 2014; Schader et al. 2015).

In the past, land expansion to produce new pastures or cropland (Searchinger et al. 2015) has resulted in significant losses of biomass and soil carbon stocks through degradation, which is already widespread and dominant in almost $20 \%$ of world's pasture area (Postel 1994; Asner et al. 2004; Gang et al. 2014). In this context, using the available grassland resources more efficiently can substantially contribute to achieving future sustainability goals incl. climate change mitigation (De Oliveira Silva et al. 2016).

This article is protected by copyright. All rights reserved. 
Despite the central role of grasslands for tackling climate change and future food security (Erb et al. 2016), quantitative global analyses of the spatial pattern and dynamics of grazing and grazing intensity (GI; e.g., the amount of NPP available for grazing removed by grazing animals in a year) are rare (but see Petz et al. 2014; Kuemmerle et al. 2013; Rufin et al. 2015). Available studies are often limited in spatial extent or to specific questions (Asner et al. 2004; Steinfeld and Gerber 2010; Milchunas and Lauenroth 1993). In addition, for many important aspects, e.g., forage use or the availability of storage systems, global data are not readily available (Kuemmerle et al. 2013).

We aim to narrow this knowledge gap by applying a Net Primary Production (NPP) perspective to systematically explore patterns and constraints of GI. Focusing on NPP allows for an integrated perspective on a central ecosystem variable (Odum and Barrett 2005; Oesterheld et al. 1999) which integrates bioclimatic (e.g., precipitation; Milchunas and Lauenroth 1993; Oesterheld et al. 1999) and edaphic factors (Asner et al. 2004) and is a key process underlying carbon storage and food production (Haberl et al. 2014). Thus, it allows analysing socio-ecological trade-offs of land-use competition (Erb et al. 2016). We focus here on the role of seasonality for $\mathrm{Gl}$, which plays an important role in determining potentials of biomass usage by creating periods of shortage and surplus. Many grasslands are characterized by strong seasonal growth patterns, with pronounced productive periods and dry or cold unproductive periods. Because livestock needs permanent feeding, such seasonal variations as well as the availability of alternative feedstuff or storage systems for forage, determine livestock density in a region.

In this work, we present an assessment of seasonality-constrained maximum GI (i.e., maximum biomass offtake levels defined by the availability of biomass in the unproductive period) and compare this potential level to currently observed levels of GI. Comparing the two metrics allows us to highlight areas where additional biomass could potentially be extracted. In our novel approach, we apply the most recent data on feed-demand, its composition and spatially explicit information about the nutritional value of grasses, while existing studies often rely on coarse estimates of feed-

This article is protected by copyright. All rights reserved. 
demand (e.g. based on assumptions about the daily dry matter intake per animal in relation to body weight; Petz et al. 2014) and biomass available for grazing. In addition, we perform a sensitivity analysis by using two different NPP products over a range of 10 years, which allows us to provide a range of estimates (e.g., 20 maps) for the potential maximum biomass extraction. We highlight areas where biomass extraction could be increased and discuss the numerous socio-economic and ecological constraints that could limit the potential at the local level. This knowledge contributes to a better understanding of maximum potentials for livestock production systems at the global level, information that is essential in the light of current trajectories in production and consumption of livestock-based products.

\section{Materials and Methods}

This analysis builds on a wide range of available data on grazing systems. We use data on the extent of natural grasslands and their NPP, as well as information on the demand of roughage, i.e., the feed-demand of sheep, goats, buffaloes or cattle covered through grazing. The data sets refer to the year 2000, except the biome maps, which represent the potential distribution of grassland biomes. We aggregate all available data sets to $0.5^{\circ}$ to cope with different spatial resolutions.

We restrict our analysis to potential grazing lands by using data on grassland biomes from three maps, the FAO Eco-floristic zones map (FAO 2008), Olson biomes (Olson et al. 2001) and the potential natural vegetation from Foley and Ramankutty (2010). In a next step, we extract areas, where all three biome maps indicate natural grassland biomes, including temperate grassland, steppe, tundra, savannah, shrubland and tropical and sub-tropical dry forests in our assessment (see Figure 1 and $\mathrm{SI}$ ). This represents a progressive restriction of our analysis to potential grazing lands and so increases the probability that each of the selected grid-cells indeed is situated in a natural grassland biome.

This article is protected by copyright. All rights reserved. 
We further restrict the resulting natural grassland area to the current extent of grazing land (within the boundaries of natural grasslands) using data from Erb et al. (2007), because large parts of natural grasslands have been converted into other land-uses (e.g., cropland or built-up land). Compared to the other maps (e.g., from Ramakutty et al. 2008 or Klein-Goldewijk et al. 2007), the Erb et al. (2007) grazing land estimate is at the upper end (similar to the FAO/IIASA 2012 map), because it considers unmanaged non-permanent grazing land as well. Hence, the resulting grazing area refers to all grazing land detected by Erb et al. (2007) occurring within the extent of natural grassland biomes (see $\mathrm{SI}$ ). All grassy land-use types outside this area are excluded from the analysis (e.g., large parts of Europe and Asia). Other maps on grazing area, in particular those by Ramankutty et al. (2008) and Klein-Goldewijk et al. (2007) largely rely on FAO statistics for pasture and hence do not account for non-permanent grazing areas and are likely to underestimate the actual grazing land extent. In fact, using another grassland map for our analysis could substantially impact our results. For this reason, we include information about how the differences in grassland area would change our results in Table (2). In addition, we exclude areas less likely used for grazing (e.g., where steep slopes $>40^{\circ}$ prevail; Robinson et al. 2014; using data from Jarvis et al. 2008), areas with tree-cover above $30 \%$ in the year 2000 using data from Hansen et al. (2013) because such areas can be considered potential forest land as well as IUCN protected areas (IUCN 2015) to exclude large game reserves.

To assess and localize feed demand and calculate Gl in the year 2000, we apply a number of data sources (Table 1). This includes the Gridded Livestock of the World (GLW) map (FAO 2007; Robinson et al. 2014) and the distribution of Livestock Production Systems (LPS; Robinson 2011). Feeddemand data for cattle, buffaloes, sheep and goats for world-regions and livestock production systems are extracted from Herrero et al. (2013). These data include information on the feed demand and composition for beef cattle, dairy cattle, sheep and goat for 28 world-regions and 8 Livestock Production Systems. Animal numbers are converted to tropical livestock units (TLU; 1 TLU $=250 \mathrm{~kg}$ body weight; FAO 2015). We distinguish between total feed-demand in tC/yr covered

This article is protected by copyright. All rights reserved. 
through grazing and other feed, i.e., feedstuff from stover, occasional feeds or grain, and we include cattle, buffaloes, sheep and goats in our analysis.

\begin{tabular}{|c|c|c|c|c|}
\hline Data-Set & Type/Resolution & Purpose & YEAR & Reference \\
\hline Grazing area, km² & Raster, $0.083^{\circ}$ & Current grazing area & 2000 & Erb et al. 2007 \\
\hline $\begin{array}{l}\text { FAO Eco-Floristic- } \\
\text { Zones }\end{array}$ & Shapefile & $\begin{array}{l}\text { Potential grassland } \\
\text { extent }\end{array}$ & Potential & FAO 2008 \\
\hline $\begin{array}{l}\text { Terrestrial } \\
\text { Ecoregions of the } \\
\text { world }\end{array}$ & Shapefile & $\begin{array}{l}\text { Potential grassland } \\
\text { extent }\end{array}$ & Potential & $\begin{array}{l}\text { Olson et al. } \\
2001\end{array}$ \\
\hline Potential Vegetation & Raster, $0.5^{\circ}$ & $\begin{array}{l}\text { Potential grassland } \\
\text { extent }\end{array}$ & Potential & $\begin{array}{l}\text { Foley and } \\
\text { Ramankutty } \\
2010\end{array}$ \\
\hline Livestock density & Raster, $0.05^{\circ}$ & $\begin{array}{l}\text { Current livestock } \\
\text { density }\end{array}$ & 2000 & FAO 2007 \\
\hline $\begin{array}{l}\text { Livestock Production } \\
\text { Systems (LPS) }\end{array}$ & Raster, $0.0083^{\circ}$ & $\begin{array}{l}\text { Distribution of } \\
\text { livestock production } \\
\text { systems }\end{array}$ & 2000 & $\begin{array}{l}\text { Robinson et al. } \\
2011\end{array}$ \\
\hline Feed demand & LPS/World regions & $\begin{array}{l}\text { Feed-demand for } \\
\text { grazing animals for } \\
\text { different LPS and } \\
\text { world-regions }\end{array}$ & 2000 & $\begin{array}{l}\text { Herrero et al. } \\
2013\end{array}$ \\
\hline $\begin{array}{l}\text { Share of Cattle, } \\
\text { Sheep and Goat on } \\
\text { total grazer's feed- } \\
\text { demand }\end{array}$ & Country-Level & $\begin{array}{l}\text { Estimate feed- } \\
\text { demand of all } \\
\text { domestic grazers }\end{array}$ & 2000 & $\begin{array}{l}\text { Krausmann et } \\
\text { al. } 2013\end{array}$ \\
\hline $\begin{array}{l}\text { Natural Net Primary } \\
\text { Production (NPP) }\end{array}$ & Raster, $0.5^{\circ}$ & $\begin{array}{l}\text { Monthly patterns of } \\
\text { NPP }\end{array}$ & 1994-2004 & ESGF 2013 \\
\hline $\begin{array}{l}\text { Length of growing } \\
\text { period }\end{array}$ & Raster, $0.083^{\circ}$ & $\begin{array}{l}\text { Length of growing } \\
\text { period }\end{array}$ & 2000 & $\begin{array}{l}\text { Van Velthuizen } \\
2007\end{array}$ \\
\hline
\end{tabular}

Table 1: List and specifications of input-datasets

This article is protected by copyright. All rights reserved. 
These 4 animal types make up for approximately $79 \%$ of the total feed-demand of all domestic grazing animals in 2000 (including cattle, buffaloes, sheep, goats, horses, asses, mules, camels and other camelids estimated by Krausmann et al. 2013).

To estimate the potential biomass supply, we use monthly NPP data from two different Earth System models, the JULES and ORCHIDEE model available from the ISI-MIP Fast-Track (ESGF 2013). We use monthly NPP data, i.e., the sum of NPP accumulated over the period of one month in tonnes carbon per grid-cell, based on model results for natural vegetation for the years 1994-2004 to delineate climatic induced variations in available NPP in natural grassland areas. The data are available at geographic resolution of $0.5^{\circ}$ and the outputs were driven by the HadGEM2-ES climate model. Using NPP data for the natural vegetation helps us avoiding inconsistencies resulting from varying assumptions concerning land-use underlying the modelling process. Please note that all estimates refer to the grassland extent for the year 2000. We decided to apply data from JULES and ORCHIDEE, two widely used model environments for global change studies. The two models differ strongly regarding their NPP estimates and represent well the uncertainty across a wider range of models. This procedure provides us with a total of 20 different estimates for each grid-cell. Because the applied NPP data represent potential natural vegetation we are not able to account for the feedback between biomass removal and primary productivity. Grazing can, for instance, increase NPP by promoting compensatory growth, or decrease NPP through biomass removal or due to trampling.

Despite the focus on grassland areas within grassland biomes, a mixture of woody and grass species is common in many regions. Hence, not the entire aboveground NPP (aNPP) is accessible for animals, e.g., leaves from trees are only partly reachable. To account for this, we reduce NPP accessibility in areas where trees are observed by current tree-cover data from Hansen et al. (2013) to 15\% (following average values from the literature; see $\mathrm{SI}$ ). This follows the assumption that tree-cover observed in potential grasslands (e.g., not converted from former forest land) would also occur in the absence of human land-use.

This article is protected by copyright. All rights reserved. 
We calculate current $\mathrm{GI}\left(\mathrm{Gl}_{\text {observed }}\right)$ by relating grazing demand (derived by multiplying the estimated biomass grazed by animals in tC/yr per TLU reported by Herrero et al. (2013) with the livestock density map) to the estimated aNPP available for grazing in the year 2000. In some pixels, this approach results in $\mathrm{GI}>100 \%$, which is likely the result of accumulated uncertainties and basically means that the modelled NPP is not sufficient to cover the estimated grazing feed-demand. To deal with this issue, we apply maximum Gl levels for world-regions and climatic zones based on a large collection of local case studies available for the period between 1966 to 2015 (see SI) to the respective grid-cells. Studies reporting GI are rare and often concentrated on hotspots like for instance Northern America, New Zealand and natural grassland areas like the Mongolian Steppe etc. For this reason, we also rely on older data to provide the best coverage of values in all worldregions. This can, of course, result in an under- or overestimation of the current maximum GI observed in some regions, but the impact of this is rather small because only very few grid-cells are subject to such a correction.

The seasonally limited maximum $\mathrm{GI}\left(\mathrm{GI}_{\text {season }}\right)$ is defined as the maximum $\mathrm{Gl}$ that can be sustained during periods of minimum biomass supply in shortage periods. Similar to $\mathrm{Gl}_{\text {observed }}$, we do not allow $\mathrm{Gl}_{\text {season }}$ to exceed the literature derived maximum $\mathrm{Gl}$ level to ensure our results are realistic and rather on the conservative side. However, simply referring to the month with the minimum biomass supply would be inappropriate because it would neglect the fact that livestock can survive nonfavourable periods by feeding on stored or old, i.e., dead biomass from earlier periods that is not yet decayed. In addition, improved management strategies such as the storage and conservation of biomass could help to achieve a better utilization of the available grass resources, but no information is available on the impact of these two factors on forage supply. To explore the range of possible impacts on $\mathrm{Gl}$, we assume that animals can survive shortage periods between 1 and 5 months. The appropriate number of months is assigned to each grid-cell using information on the length of growing period (or in other words the length of the shortage period), because this essentially determines forage availability and quality (see SI; Gerrish et al. 1998). We limit the

This article is protected by copyright. All rights reserved. 
number of months that can be survived without fresh growth to five in order to guarantee a conservative estimate, although animals even survive for longer, e.g. in regions or systems with permanent supplementary feeding. Our $\mathrm{Gl}_{\text {season }}$ estimate hence represents the grazing intensity that could be sustained in the month with the minimum biomass supply (calculated as the moving average of 1-5 months). In addition, it is important to estimate the effect of declining feed quality after the end of the growing period (decay), yet such data are not readily available at the global level. To test the effect of such a decline we assume a quality drop of $3 \%$ per week (Mobile Farms 2015) for all our calculations.

To identify areas where biomass extraction could be increased, we compare $\mathrm{Gl}_{\text {observed }}$ to $\mathrm{Gl}_{\text {season. }}$ Areas where $\mathrm{Gl}_{\text {observed }}$ is well below the seasonality induced maximum $\mathrm{Gl}\left(\mathrm{Gl}_{\text {season }}\right)$ could exhibit potential to increase biomass extraction. Increasing $\mathrm{Gl}_{\mathrm{observed}}$ to the level of $\mathrm{GI}_{\text {season }}$ could contribute to increasing milk/meat production within the boundaries set by seasonality or to release area from production. To realistically estimate how much more milk or meat could be produced from one tonne additionally available carbon, the nutritional quality of grasses must be considered. We account for this by applying data from the Herrero et al. (2013) database, who assess the information at the level of livestock production systems distinguishing world-regions.

Another interesting aspect is how the observed grazing intensity interacts with the amount of other feed fed to animals. For this analysis and the sake of simplicity we have subsumed the three classes "stover", "occasional", and "grains" reported in the original Herrero et al. 2013 data set under the category "other feed". To see how other sources of feed interact with shortage periods, we extract the number of months with insufficient biomass provision to sustain the estimated feed-demand and relate this to the total amount of other feed fed in each grid-cell. This shows how the length of seasonal limitations interact with the total demand for other feeds. As already outlined, the GI estimate is based on figures on grazing feed demand as presented by Herrero et al. (2013) and accumulated uncertainties in input-data products occasionally results in grid-cells where the

This article is protected by copyright. All rights reserved. 
available NPP is not sufficient to cover the estimated feed demand. In these grid-cells, we assume that the remainder must come from another source of feed and shift the excess to the "other feed" category. This adjustment, however, most likely interacts strongest with the "Occasional" feed category reported in the original data by Herrero et al. 2013. For this reason, the "other feed" category does not exactly reflect figures from Herrero et al. (2013) and differences highlight uncertainties in NPP, feed-demand and livestock distribution estimates.

All biomass flows, i.e., NPP and feed demand, are presented in carbon units. The study is restricted to the aboveground fraction of the total NPP by applying a factor of $60 \%$ (aNPP; House and Hall 2000) to the original NPP values. Feed-demand estimates are converted from dry-matter to carbon assuming a carbon content of 50\% (Gibbs 2006; Mackey 2008; Saatchi et al. 2011). We present our results for 11 world regions: Central Asia and Russia (CA\&RUSSIA), Eastern- and South Eastern Europe (E\&SE EUR), Eastern Asia (EA), Latin America (LAM), Northern Africa and Western Asia (NAWA), Northern America (NA), Oceania (OCE), South-Eastern Asia (SEA), Southern Asia (SA), SubSaharan Africa (SSA), Western Europe (WEUR). A flowchart displaying the major steps of the data analysis process is presented in the SI.

\section{Results}

\subsection{Grazing intensity and seasonality}

$\mathrm{Gl}_{\text {observed }}$ in world's natural grasslands lies below $15 \%$ on almost $79 \%$ of the total area (Figure 1a). On $36 \%$ of the area, $\mathrm{Gl}$ is below $2 \%$, on $56 \%$ below $5 \%$ and on $71 \%$ below $10 \%$. Very low levels of $\mathrm{GI}_{\text {observed }}$ can be found on all continents, but are particularly dominant in parts of Sub-Saharan Africa, Latin America, Central Asia and Russia, Eastern Asia and Northern America. High $\mathrm{Gl}_{\text {observed }}$ prevails in arid and semi-arid regions where it can exceed 50\%. Such areas are mostly located in Eastern Asia, Sub-Saharan Africa, Northern Africa and Western Asia and Southern Asia but cover only $4.6 \%$ of the total area. Figure $1 \mathrm{~b}$ shows the distribution of $\mathrm{Gl}_{\text {season, }}$ e.g., the potentially feasible $\mathrm{Gl}$ considering 
that animals can survive a certain time without new biomass growth (e.g., 1-5months) by feeding from dead or decaying grasses, leaves or stored biomass. In contrast to $\mathrm{Gl}_{\text {observed }}, \mathrm{Gl}_{\text {season }}$ exceeds $10 \%$ on approximately $33 \%$ of all grazing lands. $\mathrm{Gl}_{\text {season }}>10 \%$ is the dominant pattern in many parts of Latin America and Sub-Saharan Africa, areas where $\mathrm{Gl}_{\text {observed }}$ is often below $2 \%$. Other hotspots with a relatively high $\mathrm{Gl}_{\text {season }}$ are located in Northern America, parts of Europe and Eastern Australia. In arid areas (e.g., Eastern North America, the Atacama, the Sahel zone in Africa, and dry regions of Asia and Australia; see Figure $1 \mathrm{~b}$, dark blue grid-cells) $\mathrm{Gl}_{\text {season }}$ is often close to or zero, covering up to $44 \%$ of the total natural grassland area.

This article is protected by copyright. All rights reserved. 


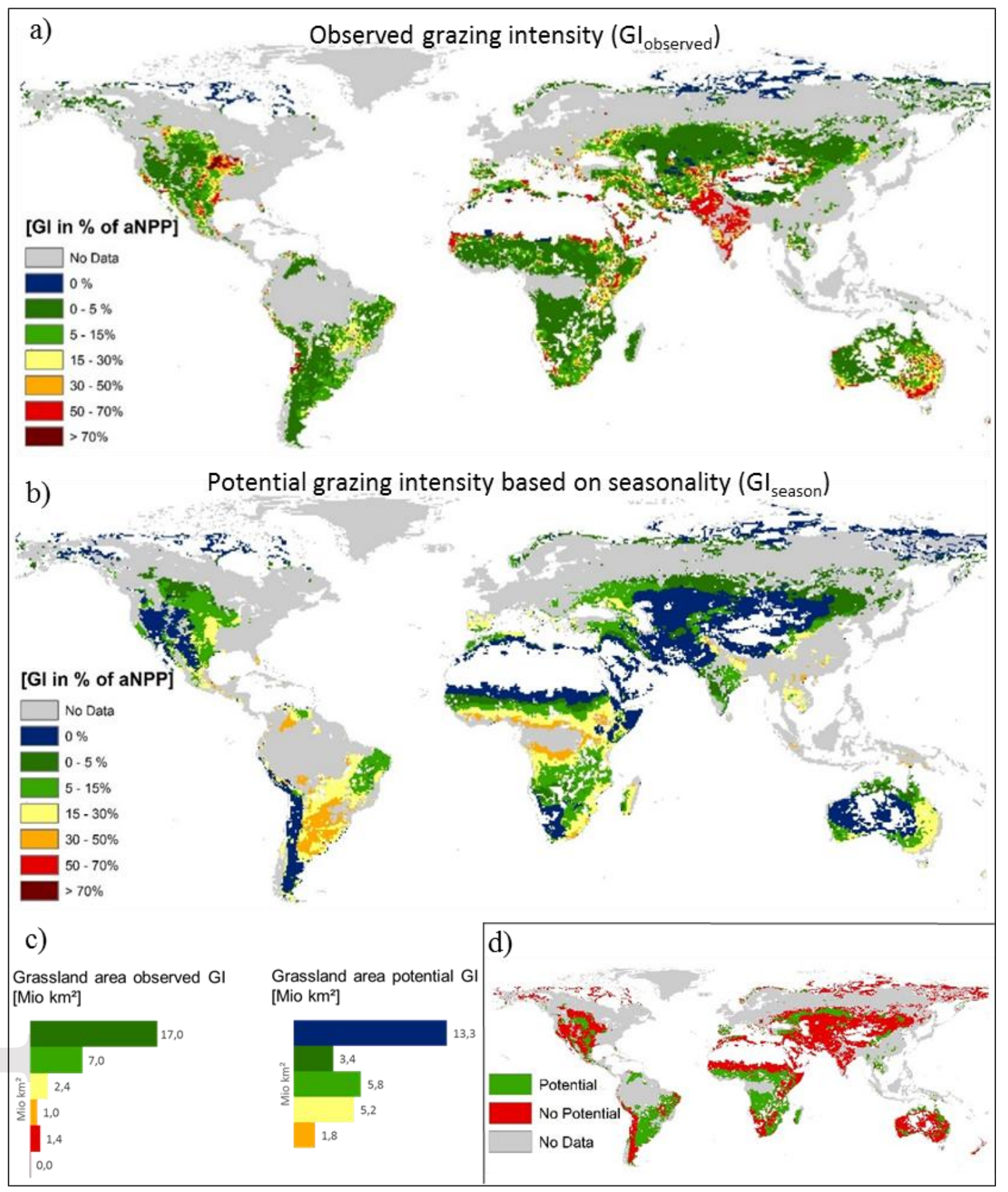

Figure 1: Global pattern of grazing intensity (GI) in natural grasslands (GI = grazing feed-demand/aNPP). a) Observed grazing intensity $\left(G I_{\text {observed }}\right)$ in the year 2000; b) potential grazing intensity based on seasonality $\left(G_{\text {season }}\right)$; c) Grassland area for each group displayed in a and $b$ for $\mathrm{Gl}_{\text {observed }}$ and $\mathrm{Gl}_{\text {season. }}$. d) Spatial distribution of areas with potential or no potential to increase $\mathrm{Gl}$. Grey areas are excluded from the assessment, because we focus on natural grassland extent only.

This article is protected by copyright. All rights reserved. 
The reason for this is that biomass supply drops to zero even when considering that animals can feed up to 5 months from dead biomass. In these areas, keeping ruminant animals requires to deal with periods of 5 months or more of feed deficiency. Assuming that more than 5 months could be bridged would eventually allow to come up with a potential for further biomass extraction in these regions and indeed it is well known that winter grazing without any supplements is not uncommon, for instance in North America. Yet, increasing biomass removals in regions with very long shortage periods would come at substantial socio-economic cost in terms of management, storage technologies and supplementary feed. Applying a maximum of 5 months hence allows to come up with a more realistic estimate and to exclude potentials associated with a very high socio-economic effort.

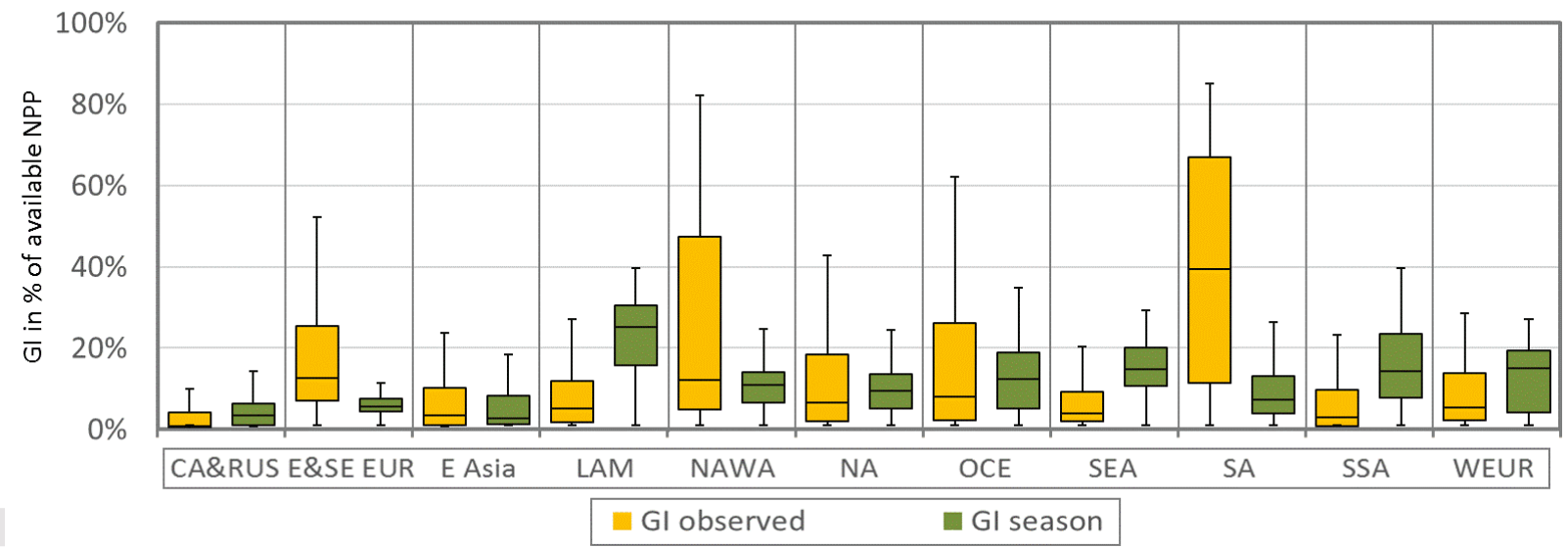

Figure 2: Boxplot of global pattern of grazing intensity (GI) in natural grasslands and world-regions for current grazing intensity $\left(\mathrm{GI}_{\text {observed }}\right)$ in the year 2000 and potential grazing intensity $\left(\mathrm{GI}_{\text {season }}\right)$. The box represents the inner quartiles, whiskers the minimum and maximum respectively. The discrepancy between $\mathrm{GI}_{\text {observed }}$ and $\mathrm{GI}_{\text {season }}$ is due to the availability of storage systems and a more efficient use of the available grass resources. World regions: CA\&RUS = Central Asia and Russia, E\&SE EUR = Eastern and South-Eastern Europe, E Asia = Eastern Asia, LAM = Latin America, NAWA = Northern Africa and Western Asia, NA = Northern America, OCE = Oceania, SEA = South-Eastern Asia, SA = Southern Asia, SSA = Sub-Saharan Africa, WEUR = Western Europe.

World-regions with dominant hotspots like Southern Asia, Northern Africa and Western Asia, North America, Oceania or Eastern and South-Eastern Europe also show a widespread distribution of $\mathrm{Gl}_{\text {observed }}$ which often exceeds $\mathrm{GI}_{\text {season }}$ (Figure 2) by far. A high $\mathrm{Gl}_{\text {observed }}$ can be explained by improved 
management (e.g., a more efficient use of the available resource) but often strongly relies on the availability of other feed sources. On the other hand, in regions like Latin America, Sub-Saharan Africa, or South-Eastern Asia $\mathrm{Gl}_{\text {observed }}$ lies significantly below $\mathrm{Gl}_{\text {season. }}$. The potential $\mathrm{GI}_{\text {season }}$ exceeds $\mathrm{Gl}_{\text {observed }}$ in Latin America (16 vs 7\%), Sub-Saharan Africa (10 vs 5\%) or South-Eastern Asia (16 vs 6\%; see Figure 3a and Table $5 \mathrm{SI}$ ). Due to variations in climatic factors, $\mathrm{Gl}_{\text {observed }}$ varies drastically between years (Figure 3b). On average, $\mathrm{Gl}_{\text {observed }}$ is highest in Southern Asia (52\%) followed by Eastern and South-Eastern Europe (22\%) and Oceania (18\%) and lowest in Central Asia and Russia (4\%) followed by Eastern Asia (5\%), Sub-Saharan Africa (5\%), South-Eastern Asia (6\%) and Latin America (7\%).

a)

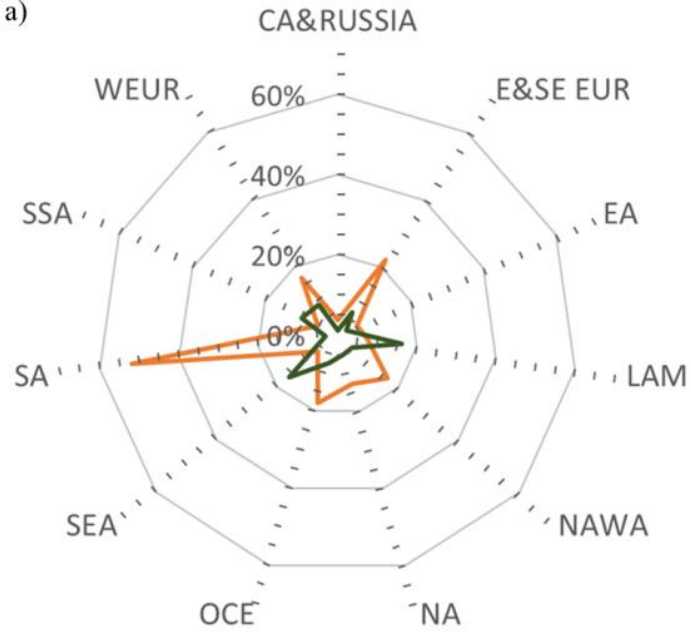

-GI observed - GI season b)

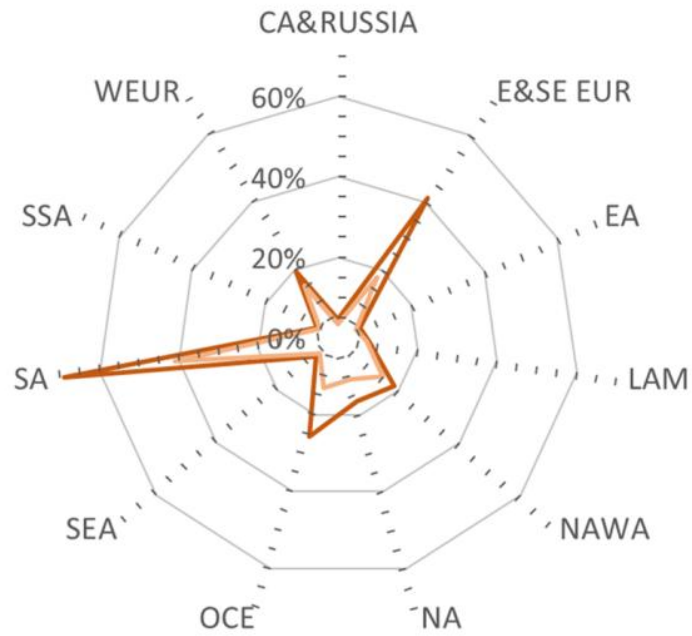

-GI observed max $\quad-$ Gl observed $\min$

Figure 3: Patterns of average $\mathrm{Gl}$ for world-regions. a) Regional averages of $\mathrm{Gl}_{\text {observed }}$ (values for the year 2000), $\mathrm{Gl}_{\text {season }}$ and b) Variation of $\mathrm{GI}_{\text {observed }}$ (minimum and maximum observed in the period 1994-2004, considering the range of estimates resulting from the two NPP data products).

Accounting for the difference between $\mathrm{Gl}_{\text {observed }}$ and the estimated $\mathrm{Gl}_{\text {season }}$ shows that within the 10 simulated years at minimum 182 Mio $\mathrm{tC} / \mathrm{yr}$ and at maximum $997 \mathrm{Mio} \mathrm{tC} / \mathrm{yr}$ of potential surplus biomass could be available before reaching the estimated $\mathrm{Gl}_{\text {season }}($

Table 2). The large range of results is mainly influenced by interannual variations in biomass supply driven by climatic variables like precipitation (Yan et al. 2015) and differences in the two NPP dataproducts. Sub-Saharan Africa (45\%) and Latin America (52\%) contribute most to the total potential.

This article is protected by copyright. All rights reserved. 
The estimated minimum potential (e.g., $182 \mathrm{Mio} \mathrm{tC/yr)} \mathrm{could} \mathrm{support} \mathrm{an} \mathrm{additional} \mathrm{milk} \mathrm{production}$ of up to $29 \mathrm{Mio} \mathrm{t} / \mathrm{milk} / \mathrm{yr}$, which is equivalent to a growth of $5 \%$ compared to the production reported by Herrero et al. (2013) for the year 2000. On the other hand, the surplus could allow an additional meat production of up to $2.6 \mathrm{Mio} \mathrm{t} / \mathrm{meat} / \mathrm{yr}(+4 \%$ compared to 2000 ) or contribute to release up to $2.8 \mathrm{Mio} \mathrm{km}^{2}$ of natural grazing lands from production.

\section{Surplus NPP in tC/yr}

\begin{tabular}{|c|c|c|c|c|c|c|}
\hline Region & Minimum & $\begin{array}{r}25 \text { th } \\
\text { quartile }\end{array}$ & Average & $\begin{array}{r}75 \text { th } \\
\text { quartile }\end{array}$ & Maximum & $\begin{array}{r}\text { Variation } \\
\text { grassland } \\
\text { area }\end{array}$ \\
\hline South-Eastern Asia & 3,3 & 8,8 & 13,1 & 19,1 & 26,8 & $-+94 / 0 \%$ \\
\hline Sub-Saharan Africa & 77,3 & 151,8 & 221,5 & 328,6 & 483,4 & $-+46 / 5 \%$ \\
\hline Latin America & 99,3 & 165,4 & 207,8 & 277,8 & 358,4 & $-+27 / 4 \%$ \\
\hline Other & 2,0 & 30,7 & 29,7 & 75,3 & 128,8 & $-+25 / 12 \%$ \\
\hline World & 181,9 & 356,8 & 472,0 & 700,8 & 997,4 & $-+38 / 4 \%$ \\
\hline
\end{tabular}

Table 2: Potentially available surplus NPP. Figures reflect the potential for further biomass extraction defined as the difference between $\mathrm{Gl}_{\text {observed }}$ and the respective estimate for $\mathrm{Gl}_{\text {season. }}$. The presented values refer to the minimum, quartiles, average and maximum for the range of values derived from the two independent NPP estimates and the ten years 1994-2004, the underlying grassland extent is constant. The last column highlights changes to the estimates resulting from varying the underlying grazing area maps (Please note that the negative variation is larger, because the Erb et al. 2007 dataset is already at the higher end of the spectrum).

\subsection{Interaction of GI, other feed sources and seasonality}

Pushing GI beyond its seasonal potential comes with an increased socio-economic cost, e.g., the need for management such as the implementation of storage facilities or the exploitation of other sources of feed to avoid overgrazing and damage to the land like soil erosion. Total estimated supplementary feed ranges between $466-510$ Mio tC/yr, the bulk of which is fed to animals in Southern Asia, Sub-Saharan Africa and Latin America (Figure 4a) in particular in mixed systems (72\%). Arid areas account for up to $59 \%$ of the global total (Figure $4 \mathrm{~b})$. Our results show that the distribution of supplementary feed is not necessarily related to seasonal limitations. Of the total

This article is protected by copyright. All rights reserved. 
other feeds, $20 \%$ are fed in areas without seasonal limitations, followed by $12 \%$ fed in areas with limitations of $1-3$ months and $18 \%$ with $4-6$ months. Up to $49 \%$ is fed in areas with very strong seasonal limitations between 7 and 11 months, mainly in Southern Asia (36\% of the global total) and smaller fractions in other world regions. In Latin America and Sub-Saharan Africa, which together make up for $35 \%$ of the global total other feed, $73 \%$ and $32 \%$ of the regional other feed is fed in areas where no seasonal constraints occur. Another 17\% in Latin America and 25\% in Sub-Saharan Africa are fed in regions, where seasonal limitations are only minor with 1-3 months of feeddeficiency. Hence, globally $32 \%$ of the total other feed is fed in regions with no or only small (1-3 months of deficiency) seasonal limitations, areas where the share of other feed could be reduced in theory. But in practice this will depend on the nutritional value of the available grasses at the specific location.

a)

200

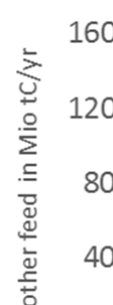

b)

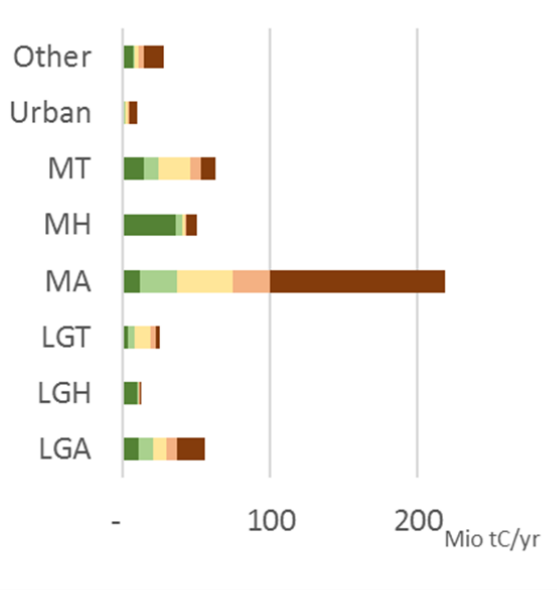

Figure 4: Supplementary feed in Mio tC/yr, divided into periods of feed-deficiency in a) world regions and b) livestock production systems: based on feed-demand Herrero et al. (2013) and accessible aNPP; LGA = Rangeland-based arid, LGH = Rangeland based humid, LGT = Rangeland based temperate/tropical highland, $\mathrm{MA}=$ Mixed arid, $\mathrm{MH}=$ Mixed humid, $\mathrm{MT}=$ Mixed temperate/tropical highland, Urban \& Other.

This article is protected by copyright. All rights reserved. 
The average other feed as presented in Figure 4 differs slightly from the data presented in Herrero et al. (2013) because in grid-cells with insufficient simulated NPP provision, we shift the remaining feed-demand from grazing to other feed categories. The necessity to adjust for this is a result of accumulated uncertainties resulting from the combination of NPP data, animal distribution, local variations in common feeding practices which cannot exactly be reflected using regional level data and problems of delineating grasslands from other land-uses.

\section{Discussion and conclusions}

The comparison of grazing intensity observed in the year 2000 ( $\left.\mathrm{Gl}_{\text {observed }}\right)$ and the potential maximum grazing intensity $\left(\mathrm{Gl}_{\text {season }}\right)$ defined by limitations of biomass supply in shortage periods reveals a theoretical potential for increasing biomass extraction from grasslands biomes between 182 and 997 Mio $\mathrm{tC} / \mathrm{yr}$ (see Table 2). The presented range is based on variations from two different NPP data products and reflects inter-annual variations in biomass supply as a result of climatic variations. $\mathrm{Gl}_{\text {observed }}$ in the year 2000 generally shows an heterogenous distribution but is low in most parts of world's natural grassland biomes. Hotspots of very high $\mathrm{Gl}_{\text {observed }}$ are located on all continents, but are particularly dominant in arid and semi-arid areas of Africa and Asia. $\mathrm{Gl}_{\text {observed }}$ lies well below the potential maximum imposed by seasonality $\left(\mathrm{Gl}_{\text {season }}\right)$ in large parts of Latin America, Sub-Saharan Africa and to a smaller extent in other world-regions. These areas theoretically exhibit the potential to increase GI to the estimated seasonal potential by applying bridging technologies like storage, biomass conservation or grazing dead standing biomass. Latin America and Sub-Saharan Africa exhibit the bulk of the estimated potential by accounting for $52 \%$ and $45 \%$ respectively. In addition, they account for up to $35 \%$ of the global total other feed fed to animals and a large fraction of this is fed in areas with no apparent seasonal limitations of biomass supply (e.g., $73 \%$ in LAM and 32\% of other feeds in SSA; see Figure 4a). Globally, feed from other sources amounts to 466-510 Mio tC/yr. Increasing $\mathrm{GI}_{\text {observed }}$ to the estimated seasonal potential $\left(\mathrm{GI}_{\text {season }}\right)$ could allow reducing the fraction of

This article is protected by copyright. All rights reserved. 
other feeds on total feed demand and at the same time keeping the production at the same level.

This could be an essential strategy to reduce environmental burdens (Schader et al. 2015) related to crop production. Increasing the utilization levels of available grass resources in the respective regions could also contribute to increasing milk or meat production or carbon sequestration by releasing areas from production. According to our conservative results (i.e., 181 Mio tC/yr) either up to $2.8 \mathrm{Mio} \mathrm{km}^{2}$ of grasslands could be released from production or the surplus NPP could contribute to increasing milk production by $5 \%$ (29.2 Mio t/yr) or meat production by $4 \%$ (2.6 Mio t/yr). The results clearly show, that there is at least some space to improve resource use efficiency by applying proper management to the current grassland resources. Yet, efforts to increasing the efficiency of livestock systems are often hampered by massive socioeconomic and institutional constraints (Alkemade et al. 2013).

\section{Regions with potential to increase biomass extraction}

We assume that it is easiest to utilize the estimated potential surplus biomass in regions, where mixed crop-livestock systems are dominant (IAC 2005; Herrero et al. 2013; Thornton 2010) and the use of crops or residues as supplementary feed is currently not well implemented or inefficient. The surplus biomass could be used by increasing animal densities and a better management of the available supplementary feeds could help to feed the animals in periods of insufficient biomass supply and lower the resilience towards extreme events. Such a situation has been reported for large parts of Sub-Saharan Africa where valuable feed sources like trees or crop residues are often not well integrated (Lenne and Thomas 2006). In these regions, a combination of better utilizing the available crop residues and grass resources could exhibit substantial potential. In contrast to the African continent, other nutrient rich sources of feed like soybean are sufficiently available and integrated in mixed livestock systems in Latin America, where cereal stovers play a less important role (Herrero et al. 2013). But the good availability of other feed sources came at the expense of massive deforestation for cropland and pasture expansion in the past 30 years (Thornton 2010) and

This article is protected by copyright. All rights reserved. 
the resulting land abundance has largely prevented efficiency improvements (Alkemade et al. 2013). Using the available pasture resources more efficiently in these regions of Latin America could hence help to avoid further deforestation, facilitating a better integration of crop residues in livestock feed and help to reduce the fraction of nutrient rich feeds like soybeans in a region where seasonal limitations are marginal.

\section{Socio-economic, abiotic and data driven limitations}

Many regions where we identify a potential to increase biomass extraction are often relatively remote with a lack of infrastructure (e.g., storage facilities, transportation), labour constraints, competition among stakeholders, a lack of market access, knowledge or finance (Lenne and Thomas 2006; Kindu et al. 2014; Jayne et al. 2014, Rufino et al. 2008; Muhereza et al. 2014), or have been identified as hotspots of biodiversity (e.g., endemism richness going along with low land use intensity in Mesoamerica, Eastern Africa or SEA; Kehoe et al. 2015).

Intensification of land-use is often related to negative environmental impacts such as the degradation of ecosystems and soils, the pollution of groundwater and air or biodiversity loss (Erb 2012; Millennium Ecosystem Assessement 2005, Tilman 2006). Negative effects of grazing have been widely discussed in the scientific community. Overgrazing and the expansion of grazing lands into pristine ecosystems (factor 6 since 1800; Steinfeld et al. 2006) for instance have resulted in soil erosion, a depletion of carbon stocks and contributed to increasing GHG emissions (O'Mara 2012). Furthermore, social problems related to the intensification of grazing systems like commodification, alterations in the access to resources or the marginalization of the poor etc. (FAO 2011) have been identified as important factors. This is particularly true for Sub-Saharan Africa where a combination of population growth, urbanization, changes in land-tenure, international land deals and restricted access to traditional grassland areas have led to widespread degradation (Conant and Paustian 2002; Jayne et al. 2014; Fetzel et al. 2016).

This article is protected by copyright. All rights reserved. 
A major issue relates to the fact that the impact of changes in ecosystem processes resulting from variations in Gl still cannot be represented well at the aggregated level (Kaplan et al. 2009). While many of these factors, like the impacts of grazing on species diversity and composition, primary productivity and hydrology are very well understood at the local level (Illius and O'Connor 1999, Noy-Meir 1975; Fynn and O'Connor 2000; Oesterheld et al. 1999; Milchunas and Lauenroth 1993; Sasaki et al. 2007), the complex interlinkage of variables like grazing history and frequency, or stocking rate, hamper an aggregated representation (Milchunas and Lauenroth 1993). Together with the essentially nonlinear responses of NPP to grazing (Sasaki et al. 2007; Oesterheld et al. 1999) the definition of generalizable thresholds for $\mathrm{Gl}$ at higher levels (e.g., regions or biomes) becomes intricate and context specific.

In addition, abiotic factors (e.g., droughts) play an essential role in determining biomass provision in arid and semi-arid regions of the world (Vetter 2004). Although the limitation of biomass through droughts is generally considered in Earth System models and hence in the applied NPP data, the limited range of our data (e.g., 10 years) may miss out on extreme drought events and introduce uncertainty to the estimated availability of biomass. As a result, livestock mortality is high (often higher than 20\% per year; Duncan et al. 2013) and herd recovery after shocks like droughts can be very slow (Lesnoff et al. 2012). Another issue is related to variations in feeding quality of grasses, which is generally considered in the data by Herrero et al. (2013), yet the regional level data are not able to appropriately capture local level variations and cannot account for abiotic factors like the impacts of droughts on the feeding quality of grasses. Also, grazing influences productivity, e.g. by reducing the total NPP through grazing and trampling or increasing NPP through compensatory growth, yet, we do not consider such interactions in our work and this could impact the actual potential at the local level.

This article is protected by copyright. All rights reserved. 


\section{Advantages of improved efficiency}

In the light of projected future sustainability challenges and issues of food security it appears timely to focus on improving the efficiency of biomass use on existing areas rather than promoting further land expansion (Fetzel et al. 2016; Herrero et al. 2013, O'Mara 2012). Our results support this notion and show that even when considering a wide range of estimates including the application of different NPP data products and considering climatic limitations imposed by interannual variations in biomass supply, some potential surplus NPP is available in most world-regions.

Despite all constraints, utilizing even parts of this potential could be an asset to food security and reduce pressure on world's croplands of which $1 / 3$ is already in use for feeding livestock (Foley et al. 2011). In addition, a better integration of crop residues and other sources of feed in animal feed would not only help to increase GI but also make farmers more resilient towards climatic fluctuations and extreme events like droughts. Yet, local constraints need to be overcome and potential (positive or negative) environmental trade-offs must be considered carefully. Sound, regionally balanced management strategies in combination with sustainable intensification measures targeted at increasing productivity could generate substantial benefits by helping to reduce the fraction of other feed, increasing production, restoring degraded lands and even contribute to reduce GHG emissions by promoting carbon sequestration in soil carbon stocks (Soussanna et al. 2013; Schader et al. 2015). In addition, alleviating land competition by reducing the pressure on croplands for animal feeding could have positive net effects on many environmental variables due to the favourable energy balance of cropland over animal products (Schader et al. 2015).

Our results provide strong evidence that there is potential to use the available resource more efficiently by promoting improved grazing management. Measures should target at the improvement of the knowledge base of land users and include management practices such as timing, duration and spatial distribution of grazing (rotational grazing), appropriate stocking rates,

This article is protected by copyright. All rights reserved. 
the implementation of storage facilities, sowing of legumes and high productive species, fire management, fertilization and the promotion of an efficient integration of other feed sources and the conservation of forage in storage systems where possible (Sternberg et al. 2000; Lal, 2004; Smith et al 2007; NRCS 2011; Henderson et al. 2015). Achieving this potential might be a challenge in areas where abiotic factors like precipitation result in extended droughts and hence limited biomass availability in some years. It is the combination of several factors like the availability of and ability to buy supplementary feeds, a certain flexibility of farmers to alter herd size, the implementation of storage systems and free access to infrequently used grazing areas (e.g., in transhumance systems) that could help extracting more biomass. Free accessibility is an essential strategy to coping with the effects of droughts (Bayer and Waters-Bayer 1994) and indeed, it has been argued that restricting pastoralists access to historically grazed areas resulted in increased grazing pressure and local degradation in the remaining areas (Vetter 2004). A combination of the storage of excess biomass from surplus periods from either grasslands or croplands (crop residues or fodder-crops), free access to traditionally used land and a good market access which could help farmers to quickly adapting stocking density or buy supplementary feeds could help tackling the risks of increasing stocking densities in these regions.

Grasslands are an important asset for humans providing food and income for many people and grazing allows the utilization of land not suitable for other land-uses such as cropping and is vital for maintaining food security. Grasslands also play an essential role for increasing food production to meet projected future food demands. To achieve this target in a sustainable manner, it appears timely to focus on a more efficient use of the currently available land-resources instead of promoting further land expansion. By mapping grazing intensity and seasonal constraints to $\mathrm{Gl}$ at the global level, we show that advanced management would allow compensating (at least partly) for seasonality-related feed-shortages on $39 \%$ of natural grasslands, e.g., by implementing storage systems or proper management of grazing (in terms of onset, duration and recovery time) and the better integration of already available other feeds. Warranting cautious and sensible management,

This article is protected by copyright. All rights reserved. 
mobilizing these potentials could free a considerable biomass flow, mainly in Sub-Saharan Africa and more realistically in Latin America. However, the required knowledge for such a best-practice grassland management, e.g., on safe levels of grazing intensity, onset, duration and timing of grazing, as well as the implementation of storage facilities that can help to better utilize the available resources, is still limited. To reap the socio-economic and environmental benefits related to the mobilization of such a potential, while avoiding socioecological detriments requires a significantly advanced understanding of grazing systems as well as proper policy frameworks that integrate local, regional and global socio-economic and ecological perspectives.

\section{Acknowledgements}

This work was conducted during the Young Scientists Summer Program 2015 at the International Institute for Applied Systems Analysis (IIASA), in Laxenburg, Austria. The authors would like to thank the IIASA staff for providing this research opportunity, technical support and many discussions. We thank the three anonymous reviewers for their constructive comments and suggestions that significantly improved the manuscript. Funding for the YSSP 2015 program by the (Bundesministerium für Wissenschaft, Forschung und Wirtschaft) and from the ERC Starting Grant 2010263522 (LUISE) is acknowledged. MH acknowledges support from the Belmont Forum/FACCEJPI funded DEVIL project (Delivering Food Security on Limited Land - NE/M021327/1). The study contributes to the Global Land Project (www.globallandproject.org).

This article is protected by copyright. All rights reserved. 


\section{References}

Alkemade R, Reid RS, Van den Berg M, De Leeuw J, Jeuken M (2013) Assessing the impacts of livestock production on biodiversity in rangeland ecosystems. PNAS, 110 (52), 20900-20905.

Asner GP, Elmore AJ, Olander LP, Martin RE, Harris AT (2004) Grazing systems, ecosystem responses, and global change. Annu. Rev. Environ. Resourc, 29(1), 261-299.

Bayer W and Waters-Bayer A (1994) Forage alternatives from range and field: Pastoral forage management and improvement in the African drylands, in Living with uncertainty: New directions in pastoral development in Africa. In: Living with uncertainty: New directions in pastoral development in Africa. London: Intermediate Technology

Conant RT, Paustian K (2002) Potential soil carbon sequestration in overgrazed grassland ecosystems. Global Biogeochemical Cycles, 16 (4), 901-909.

De Oliveira Silva R, Barioni LG, Hall JAJ, Folegatti Matsuura M, Zanett Albertini T, Fernandes FA, Moran D (2016) Decoupling livestock production from deforestation in Brazil: how increasing beef consumption can lower greenhouse gas emissions, 2015. Nature Climate Change. DOI: 10.1038/NCLIMATE2916

Duncan AJ, Tarawali SA, Thorne PJ, Valbuena D, Descheemaeker K, Homann-Kee Tui S (2013) Integrated crop-livestock systems - a key to sustainable intensification in Africa. Tropical Grasslands - Forrajes Tropicales, 1, 202-206.

Erb KH, Gaube V, Krausmann F, Plutzar C, Bondeau A, Haberl H (2007) A comprehesive global 5 min resolution land-use data set for the year 2000 consistent with national census data. Journal of Land Use Science, 2 (3),191-224.

This article is protected by copyright. All rights reserved. 
Erb KH (2012) How a socio-ecological metabolism approach can help to advance our understanding of changes in land-use intensity. Ecological Economics, 76, 8-14.

Erb KH, Lauk C, Kastner T, Mayer A, Theurl MC, Haberl H (2016) Exploring the biophysical option space for feeding the world without deforestation. Nature Communications, 7, doi:10.1038/ncomms11382.

ESGF (2013) Monthly NPP data 1971 - 2005. http://esg.pik-potsdam.de/esgf-web-fe/. Accessed 02.2015

FAO (2007) Gridded livestock of the World. Food and Agricultural Organization. ftp://ftp.fao.org/docrep/fao/010/a1259e/a1259e00.pdf. Accessed: 02.2013

FAO (2008) Global ecofloristic zones mapped by the United Nations Food and Agricultural Organization. http://cdiac.ornl.gov/epubs/ndp/global_carbon/carbon_documentation.html. Accessed: 07.2015

FAO (2011) World Livestock 2011: Livestock in food security. Food and Agriculture Organization of the United Nations. http://www.fao.org/docrep/014/i2373e/i2373e.pdf. Accessed: 07.2015

FAO (2015) Tropical Livestock Units (TLU). http://www.fao.org/ag/againfo/programmes/en/lead/toolbox/Mixed1/TLU.htm. Accessed 08.2015

FAO/IIASA (2012) Global Agro-ecological Zones (GAEZ v3.0). FAO, Rome, Italy and IIASA, Laxenburg, Austria.

Fetzel T, Niedertscheider M, Haberl H, Krausmann F, Erb KH. (2016) Patterns and changes of land use and land use efficiency in Africa 1980-2005. An analysis based on the Human Appropriation of Net Primary Production framework. Regional Environmental Change, 16 (5). 1507-1520.

This article is protected by copyright. All rights reserved. 
Foley JA, Ramankutty N (2010) ISLSCP II Potential Natural Vegetation Cover. Oak Ridge National Laboratory Distributed Active Archive Center, Oak Ridge, Tennessee, Hall, Forest G., G. Collatz, B. Meeson, S. Los, E. Brown de Colstoun, and D. Landis (eds.). ISLSCP Initiative II Collection. Data set.

Foley JA, Ramankutty N, Brauman KA et al. (2011) Solutions for a cultivated planet. Nature 478, 337342.

Fynn RWS, O'Connor TG (2000) Effect of stocking rate and rainfall on rangeland dynamics and cattle performance in a semi-arid savanna. South Africa. Journal of Applied Ecology, 37, 491-507.

Gang C, Zhou W, Chen Y et al. (2014) Quantitative assessment of the contributions of climate change and human activities on global grassland degradation. Environ Earth Sci, 72 (11), 4273-4282.

Gerrish JR, Martz FH, Tate VG, Morrow RE (1998) Length of Growing Period: Does it really matter? AGRIS, (7), 26-30.

Gibbs H (2006) Olson's Major World Ecosystem Complexes Ranked by Carbon in Live Vegetation: An Updated Database using the GLC2000 Land Cover Product. http://cdiac.ornl.gov/epubs/ndp/ndp017/-ndp017b.html. Accessed 07.2015

Godfray HCJ, Beddington JR, Crute IR et al. (2010) Food Security: The Challenge of Feeding 9 Billion People. Science, 327, 812-818.

Haberl H, Erb KH, Krausmann F (2014) Human Appropriation of Net Primary Production: Patterns, Trends, and Planetary Boundaries. Annual Review of Environment and Resources, 39, 363-391.

Hansen MC, Potapov PV, Moore R et al. (2013) High-resolution global maps of 21st-century forest cover change. Science, 342 (6160), 850-853.

Havlik P, Valin H, Mosnier A et al. (2012) Crop Productivity and the global livestock sector: implications for land use change and greenhouse gas emissions. Amer. J. Agr. Econ, 94 (2), $442-$ 448.

This article is protected by copyright. All rights reserved. 
Henderson BB, Gerber JG, Hilinski TE, Falcucci A, Ojima DS, Salvatore M, Conant RT (2015)

Greenhouse gas mitigation potential of the world's grazing lands: Modeling soil carbon and nitrogen fluxes of mitigation practices. Agriculture, Ecosystems \& Environment, 207, 91-100.

Herrero M, Thornton PK, Gerber P, Reid RS (2009) Livestock, livelihoods and the environment: understanding the trade-offs. Current Opinion in Environmental Sustainability, 1 (2), 111-120.

Herrero M, Havlik P, Valin $\mathrm{H}$ et al. (2013) Biomass use, production, feed efficiencies, and greenhouse gas emissions from global livestock systems. Proceedings of the National Academy of Sciences, 110 (52). 20888-20893.

Herrero M, Thornton PK (2013) Livestock and global change: Emerging issues for sustainable food systems. PNAS, 110 (52), 20878-20881.

House JI, Hall DO (2000) Productivity in tropical savannas and grasslands. In: Terrestrial Global Productivity. (eds Roy J, Saugier B, Mooney HA). PP. 363-400. Academic Press, San Diego.

IAC (2005) Realizing the Promise and Potential of African Agriculture, Inter-Academy Council Report, March, www.interacademycouncil.net. Accessed 07.2015

Illius AW and O'Connor TG (1999) On the Relevance of Nonequilibrium concepts to arid and semiarid grazing systems. Ecological Application, 9 (3), 798

IUCN (2015) Protected Planet. http://www.iucn.org/about/work/programmes/gpap_home/. Accessed 08.2015

Jarvis A, Reuter HI, Nelson A, Geuvara E (2008) Hole-filled seamless SRTM data V4. http://srtm.csi.cgiar.org/ Accessed 07.2015

Jayne T, Chamberlin J, Headey DD (2014) Land pressures, the evolution of farming systems, and development strategies in Africa: A synthesis. Food Policy, 48,1-17.

This article is protected by copyright. All rights reserved. 
Kaplan J, Krumhardt K, Zimmermann N (2009) The prehistoric and preindustrial deforestation of Europe. Quaternary Science Reviews, 28, 3016-3034

Kehoe L, Kuemmerle T, Meyer C, Levers C, Václavík T, Kreft H, Essl F (2015) Global patterns of agricultural land-use intensity and vertebrate diversity. Diversity and Distributions, 21 (11), 13081318.

Kindu M, Duncan AJ, Valbuena D, Gerard B, Dagnachew L, Mesfin B, Gedion J (2014) Intensification of Crop-Livestock Farming Systems in East Africa: A Comparision of Selected Sites in the Highlands of Ethiopia and Kenya. In: Challenges and Opportunities for Agricultural Intensification of the Humid Highland Systems of Sub-Saharan Africa. (eds B. Vanlauwe et al.). Publishing Switzerland, Springer International.

Klein Goldewijk K, Van Drecht G, Bouwman AF (2007) Mapping contemporary global cropland and grassland distributions on a $5 \times 5$ minute resolution. J. Land Use Sci, 2, 167-190.

Krausmann F, Erb K, Gingrich S et al. (2013) Global human appropriation of net primary production doubled in the 20th century. Proceedings of the National Academy of Sciences, 110 (25), 1032410329.

Kuemmerle T, Erb K, Meyfroidt P et al. (2013) Challenges and opportunities in mapping land use intensity globally. Current Opinion in Environmental Sustainability, 5 (5), 484-493.

Lal R (2004) Soil Carbon Sequestration impacts on Global Climate Change and Food Security. Science, $304,1623-1626$.

Lenné JM, Thomas D (2006) Integrating crop-livestock research and development in Sub-Saharan Africa. Option, imperative or impossible? Outlook on Agriculture, 35 (3), 167-175.

Lesnoff M, Corniaux C, Hiernaux P (2012) Sensitivity analysis of the recovery dynamics of a cattle population following drought in the Sahel region. Ecological Modelling, 232, 28-39.

This article is protected by copyright. All rights reserved. 
Mackey B (2008) Green carbon: The role of natural forest in carbon storage. ANU E Press, Acton, A.C.T. $48 p$.

Milchunas DG, Lauenroth WK (1993) Quantitative Effects of Grazing on Vegetation and Soils Over a Global Range of Environments. Ecological Monographs, 63(4), 327.

Millennium Ecosystem Assessment (2005) Ecosystems and Human Well-being: Current State and Trends, Volume 1. Island Press, Washington, D.C

Mobile Farms (2015) Grazing and Grass Quality. http://www.mobilefarmapps.com/articles/grazingand-grass-quality.html. Accessed 09.2015

Muhereza I, Pritchard D, Murray-Prior R (2014) Utilisation of cattle manure and inorganic fertiliser for food production in central Uganda. Journal of Agriculture and Environment for International Development, 108 (2),135-151.

Noy-Meir I (1975). Stability of grazing systems: an application of predator-prey graphs. Journal of Ecology, 63, 459-481.

NRCS (2011) Range Management: Rangeland Inventory. Fact Sheet. Natural Resource Conservation Service. http://www.nrcs.usda.gov/Internet/FSE_DOCUMENTS/-stelprdb1176773.pdf. Accessed: 12.2015

Odum EP, Barrett GW (2005) Fundamentals of ecology, 5th edn. Thomson Brooks/Cole, Belmont, CA. $624 p$.

Oesterheld M, Loreti J, Semmartin M, Paruelo JM (1999) Grazing, Fire, and Climate Effects on Primary Productivity of Grasslands and Savannas. In: Ecosystems of disturbed ground. (ed Walker LR). Elsevier, Amsterdam, Oxford.

Olson DM, Dinerstein E, Wikramanayake ED et al. (2001) Terrestrial Ecoregions of the World: A New Map of Life on Earth. BioScience, 51 (11), 933-938.

This article is protected by copyright. All rights reserved. 
O'Mara FP (2012) The role of grasslands in food security and climate change. Annals of Botany, 110(6),1263-1270.

Peters M, Herrero M, Fisher $M$ et al. 2013. Challenges and opportunities for improving eco-efficiency of tropical forage-based systems to mitigate greenhouse gas emissions. Tropical Grasslands Forrajes Tropicales, 1,156-167.

Petz K, Alkemade R, Bakkenes M, Schulp CJ, Van der Velde M, Leemans R (2014) Mapping and modelling trade-offs and synergies between grazing intensity and ecosystem services in rangelands using global-scale datasets and models. Global Environmental Change, 29, 223-234.

Postel S (1994) Carrying Capacity: Earth's Bottom Line. Challenge, 37 (2), 4-12.

Ramankutty N, Evan AT, Monfreda C, Foley JA (2008) Farming the planet: 1. Geographic distribution of global agricultural lands in the year 2000. Glob. Biogeochem. Cycles 22, GB1003.

Robinson TP (2011) Global livestock production systems. Food and Agriculture Organization of the United Nations, Rome, 171p.

Robinson TP, Wint GRW, Conchedda G et al. (2014) Mapping the Global Distribution of Livestock. PLOS ONE, 9(5), e96084.

Rufin P, Müller H, Pflugmacher D, Hostert P (2015). Land use intensity trajectories on Amazonian pastures derived from Landsat time series. International Journal of Applied Earth Observation and Geoinformation, 41, 1-10.

Rufino MC (2008) Quantifying the contribution of crop-livestock integration to African farming. PhD Thesis. University of Wageningen. 294p.

Saatchi SS, Harris NL, Brown S. et al. (2011) Benchmark map of forest carbon stocks in tropical regions across three continents. Proceedings of the National Academy of Sciences, 108 (24), 9899-9904.

This article is protected by copyright. All rights reserved. 
Sasaki T, Okayasu T, Jamsran U, Takeuchi K (2007) Threshold changes in vegetation along a grazing gradient in Mongolian rangelands. J Ecology, 0(0),071106211313003

Schader C, Muller A, Scialabba NEH et al. (2015) Impacts of feeding less food-competing feedstuffs to livestock on global food system sustainability. J. R.Soc. Interface, 12 (113).

Searchinger TD, Estes L, Thornton PK et al. (2015) High carbon and biodiversity costs from converting Africa's wet savannahs to cropland. Nature Clim. Change, 5, 481-486.

Smith P, Martino D, Cai Z et al. (2007) Agriculture. In: Climate Change 2007: Mitigation. Contribution of Working Group III to the Fourth Assessment Report of the Intergovernmental Panel on Climate Change. (eds Metz B, Davidson OR, Bosch PR, Dave R, Meyer LA), p. 497-540. Cambridge University Press

Soussana JF, Barioni LG, Ari TB et al. (2013) Managing grassland systems in a changing climate: the search for practical solutions. Revitalizing grasslands to sustain our communities (eds Michalk DL et al.), PP 10-27. Proceedings of the 22nd International Grassland Congress.

Steinfeld H, Gerber P, Wassenaar T, Castel V, De Haan C (2006) Livestock's Long Shadow. Environmental Issues and Options. FAO.

Steinfeld H, Gerber PJ (2010) Livestock in a changing landscape. Island Press, Washington, London

Sternberg M, Gutman M, Perevolotksy A, Ungar ED, Kigel J (2000) Vegetation response to grazing management in a Mediterranean herbaceous community: a functional group approach. Journal of Applied Ecology, 37, 224-237.

Thornton P (2002) Mapping poverty and livestock in the developing world. International Livestock Research Institute, Nairobi, Kenya

Thornton PK (2010) Livestock production: recent trends, future prospects. Philosophical Trans. R. Soc. B., 365, 2853-2867.

This article is protected by copyright. All rights reserved. 
Tilman D, Reich PB, Knops JMH (2006) Biodiversity and ecosystem stability in a decade-long

grassland experiment. Nature, 441 (7093), 629-632.

Tilman D, Clark M (2014) Global diets link environmental sustainability and human health. Nature,

515 (7528), 518-522.

Van Velthuizen H (2007) Mapping biophysical factors that influence agricultural production and rural vulnerability. Food and Agriculture Organization of the United Nations (Environment and natural resources series, 11). Rome.

Vetter S (2004) Equilibrium and non-equilibrium in rangelands - a review of the debate. In: Vetter (2004) Rangelands at Equilibrium and Non-Equilibrium - Recent developments in the debate around rangeland ecology and management. Programme for Land and Agririan Studies, Bellville Yan H, Liang C, Li Z, Liu Z, Miao B, He C, Sheng L (2015) Impact of Precipitation Patterns on Biomass and Species Richness of Annuals in a Dry Steppe. PLOS one, 10(4), e0125300.

Figure 5: Global pattern of grazing intensity (GI) in natural grasslands (GI = grazing feed-demand/aNPP). a) Observed grazing intensity $\left(\mathrm{Gl}_{\text {observed }}\right)$ in the year 2000 ; b) potential grazing intensity based on seasonality $\left(\mathrm{GI}_{\text {season }}\right)$; c) Grassland area for each group displayed in a and $b$ for $\mathrm{Gl}_{\text {observed }}$ and $\mathrm{Gl}_{\text {season. }}$. d) Spatial distribution of areas with potential or no potential to increase GI. Grey areas are excluded from the assessment, because we focus on natural grassland extent only.

Figure 6: Boxplot of global pattern of grazing intensity (GI) in natural grasslands and world-regions for current grazing intensity $\left(\mathrm{Gl}_{\text {observed }}\right)$ in the year 2000 and potential grazing intensity $\left(\mathrm{GI}_{\text {season }}\right)$. The box represents the inner quartiles, whiskers the minimum and maximum respectively. The discrepancy between $\mathrm{Gl}_{\text {observed }}$ and $\mathrm{Gl}_{\text {season }}$ is due to the availability of storage systems and a more efficient use of the available grass resources. World regions: CA\&RUS = Central Asia and Russia, E\&SE EUR = Eastern and South-Eastern Europe, E Asia = Eastern Asia, LAM = Latin America, NAWA = Northern Africa and Western Asia, NA = Northern America, OCE $=$ Oceania, SEA = South-Eastern Asia, SA = Southern Asia, SSA = Sub-Saharan Africa, WEUR = Western Europe.

Figure 7: Patterns of average $\mathrm{Gl}$ for world-regions. a) Regional averages of $\mathrm{Gl}_{\text {observed }}$ (values for the year 2000), $\mathrm{Gl}_{\text {season }}$ and b) Variation of $\mathrm{Gl}_{\text {observed }}$ (minimum and maximum observed in the period $1994-2004$, considering the range of estimates resulting from the two NPP data products).

Figure 8: Supplementary feed in Mio tC/yr, divided into periods of feed-deficiency in a) world regions and b) livestock production systems: based on feed-demand Herrero et al. (2013) and accessible aNPP; LGA = Rangeland-based arid, LGH = Rangeland based humid, LGT = Rangeland based temperate/tropical highland, MA = Mixed arid, MH = Mixed humid, $\mathrm{MT}=$ Mixed temperate/tropical highland, Urban \& Other.

Table 3: List and specifications of input-datasets

Table 4: Potentially available surplus NPP. Figures reflect the potential for further biomass extraction defined as the difference between $\mathrm{Gl}_{\text {observed }}$ and the respective estimate for $\mathrm{Gl}_{\text {season. }}$. The presented values refer to the minimum, quartiles, average and maximum for the range of values derived from the two independent NPP estimates and the ten years 1994-2004, the underlying grassland extent is constant. The last column highlights changes to the estimates resulting from varying the underlying grazing area maps (Please note that the negative variation is larger, because the Erb et al. 2007 dataset is already at the higher end of the spectrum).

This article is protected by copyright. All rights reserved. 